\section{Exceptions to bed-controlled ice sheet flow and retreat from glaciated continental margins worldwide}

\author{
Sarah L. Greenwood ${ }^{1{ }^{\dagger}}$, Lauren M. Simkins ${ }^{2 \dagger}$, Monica C. M. Winsborrow ${ }^{3 \dagger}$, Lilja R. Bjarnadóttir ${ }^{4 \dagger}$
}

Projections of ice sheet behavior hinge on how ice flow velocity evolves and the extent to which marine-based grounding lines are stable. Ice flow and grounding line retreat are variably governed by the coupling between the ice and underlying terrain. We ask to what degree catchment-scale bed characteristics determine ice flow and retreat, drawing on paleo-ice sheet landform imprints from 99 sites on continental shelves worldwide. We find that topographic setting has broadly steered ice flow and that the bed slope favors particular styles of retreat. However, we find exceptions to accepted "rules" of behavior: Regional topographic highs are not always an impediment to fast ice flow, retreat may proceed in a controlled, steady manner on reverse slopes and, unexpectedly, the occurrence of ice streaming is not favored on a particular geological substrate. Furthermore, once grounding line retreat is under way, readvance is rarely observed regardless of regional bed characteristics.

\section{INTRODUCTION}

Basal topography and substrate conditions are widely considered to be important controls on ice sheet flow and retreat, modulating behavior across entire catchments. However, few efforts assess the ubiquity with which these controls govern both the style of ice flow and retreat across many glacial systems, despite current concerns over ice sheet stability and reducing the uncertainty gap in predictive ice sheet models.

Thermomechanical feedbacks on ice flow lead to the self-organization of ice sheets into discrete, fast-flowing ice streams and wider regions of slow flow. Numerical modeling indicates that, on a homogeneous bed, a radial pattern of ice streams emerges with regular spacing, but this spacing is disrupted in the presence of bed topographic or substrate heterogeneity (1-3). Bed topography steers ice streams (4) and sets up marine ice sheet instability (MISI; 5) by affecting ice thickness, flux, and buoyancy at marine-based grounding lines (6). Substrate geology dictates ice-bed coupling via basal resistance and feedbacks with the subglacial meltwater system either in the presence or absence of unconsolidated sediments (7-11).

Paleostudies from glaciated continental shelves similarly recognize first-order roles of topography and substrate geology, with evidence that grounded ice in different topographic settings (e.g., troughs and banks; Materials and Methods) behaves differently $(12,13)$ and that some bed substrates trigger predictable responses in the style and rate of ice flow and retreat (14). Crucially, these arguments imply that the firstorder evolution of ice sheets may be predicted on the basis of their topographic and geological setting - a particular setting will support a particular, potentially unique style of ice flow or grounding line retreat.

Ever-increasing coverage of bathymetric data with meter to submeter resolution and overlapping data survey lines on glaciated continental shelves reveals detailed landform assemblages that were shaped under flow and retreat regimes of marine-based ice sheet sectors during and since the Last Glacial Maximum (15). Here, we

\footnotetext{
1'Department of Geological Sciences, Stockholm University, 10691 Stockholm, Sweden. ${ }^{2}$ Department of Environmental Sciences, University of Virginia, Charlottesville, VA USA. ${ }^{3}$ Centre for Arctic Gas Hydrate, Environment and Climate, Department of Geosciences, UiT The Arctic University of Norway, 9037 Tromsø, Norway. ${ }^{4}$ Geological Survey of Norway, 7491 Trondheim, Norway.

*Corresponding author. Email: sarah.greenwood@geo.su.se

†All authors contributed equally to this work.
}

collate and analyze geomorphic records of ice flow and retreat from 99 locations around the world (Fig. 1 and table S1) to assess the extent to which theoretical, numerical, and conceptual models of bed-driven ice behavior are valid. Across geographically variable environments (with respect to sea level, climate, and ocean conditions), we ask to what degree ice flow and retreat styles correspond systematically to their regional-scale bed settings. An overarching goal is to be able to determine bed properties, if any, under which we can expect consistent (i.e., predictable) ice sheet behavior and conditions under which either flow or margin retreat is instead unpredictable.

\section{Predicted bed controls on marine-based ice sheet behavior Topographic landscape}

Compared to surrounding areas, the thicker ice found within confined topographic settings, like troughs and fjords (Materials and Methods), will have a lower pressure melting point, enhanced frictional heat production, and a greater insulating capacity (16). These conditions promote enhanced basal sliding and ice deformation, while mass conservation dictates that topographic funneling should drive along-flow ice acceleration. In contrast, banks (i.e., regionalscale topographic highs) are often associated with thinner and diverging ice; their relatively restricted catchments and weaker thermomechanical feedback inhibit basal melting and ice deformation compared to troughs and fjords. Broad basins may lead to flow convergence but lack strong topographic funneling that would lead to flow acceleration. We therefore predict that troughs and fjords are associated with streaming ice flow and warm-based conditions and that banks and basins more commonly house nonstreaming ice flow with more variable thermal regimes.

Laterally confined ice systems will experience enhanced lateral drag compared with ice in unconfined settings (17). Ice margin stabilization will therefore be particularly strong through narrow trough sections (18). Such confined topography will also favor the formation of buttressing ice shelves, which, in turn, stabilize ice margins by reducing grounding line ice flux (19). On the other hand, the relatively greater water depth in troughs drives the grounding line toward buoyancy and provides pathways for warm water incursion toward the grounding line $(20,21)$, while shallower bank settings suppress these processes and should favor more stable grounding lines. We predict that both lateral stresses and depth-related processes are 

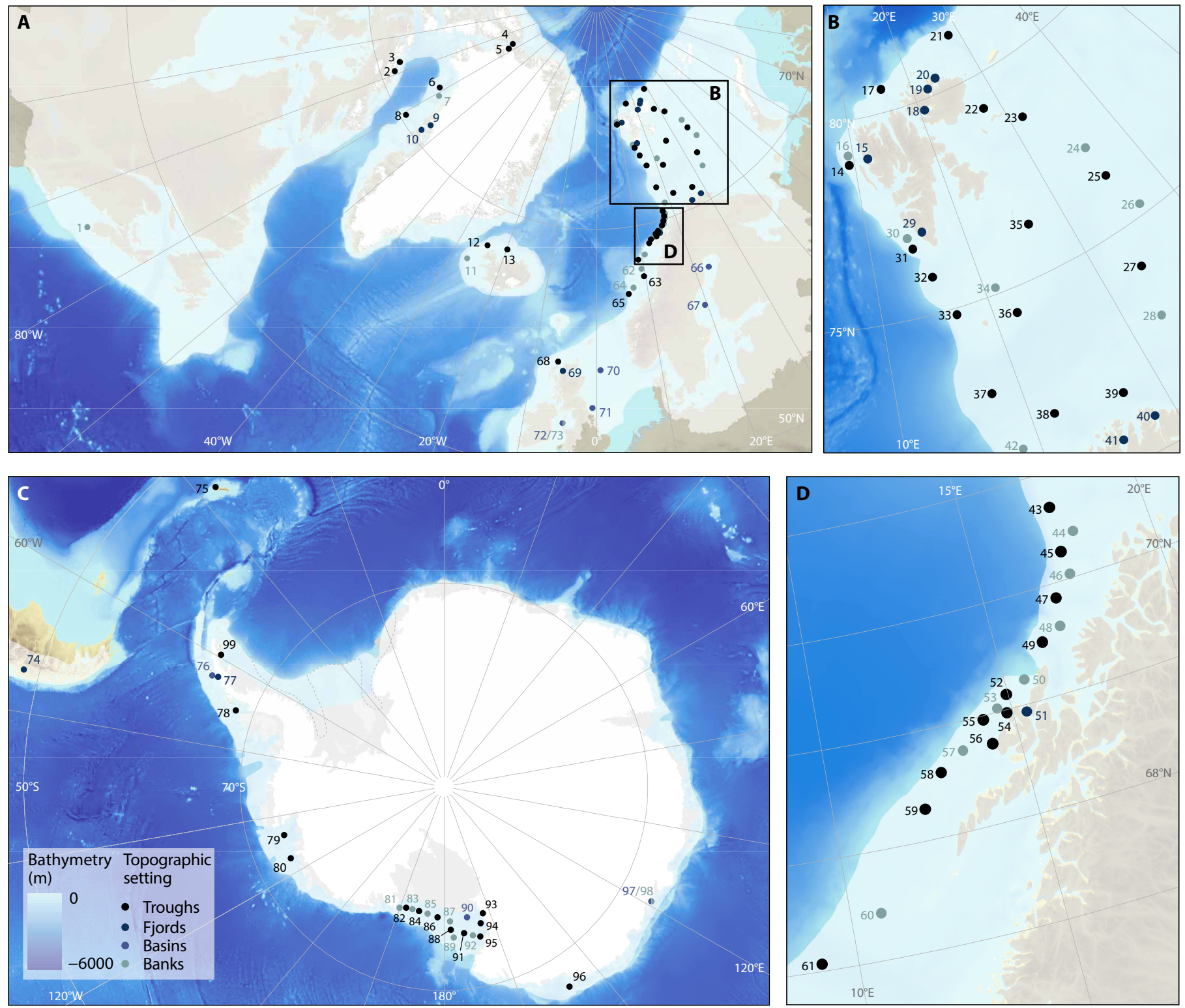

Fig. 1. Distribution of sites (99) from which high-resolution bathymetric data are available and from which we have analyzed glacial landform assemblages. Sites in the Northern Hemisphere (A, B, and $\mathbf{D}$ ) and Southern Hemisphere (C) are characterized by their regional topographic setting (troughs, fjords, basins, and banks). Numbers correspond to site numbers in table $\mathrm{S} 1$ and are referenced in subsequent figures. Topography and bathymetry are from ETOPO global terrain model. Last Glacial Maximum extent after $(54,55)$.

influential in (de)stabilizing ice margins; however, the response depends on the relative magnitude between the two.

\section{Bed slope}

While ice surface slope is the greater driver of ice flow (16), the direction of regional bed slope with respect to ice flow direction (i.e., aspect) should also affect ice flow regime via its influence on gravitational driving stress, leading to accelerated ice flow on normal slopes. On reverse (i.e., retrograde) beds, driving stress is offset by basal resistance of ice flow onto a shallowing bed (6). We predict more cases of streaming flow velocities on regionally normal bed slopes than on reverse beds and more variable flow conditions on beds with mixed bed slopes.
The MISI theory states that a bed that is below sea level and that deepens toward the ice divide cannot have a stable ice sheet grounding line (5). Ever thicker ice is required to maintain grounding during retreat, while the discharge flux simultaneously increases because of the greater ice thickness at the grounding line. Without a match in upstream accumulation, thinning and retreat propagate inland into yet deeper water. However, spatiotemporally variable bed conditions, ice shelf buttressing, and lateral drag may offset the tendency of marine-based grounding lines to irreversibly retreat on reverse beds $(18,22,23)$. In the absence of such modulation, we predict that paleo-observations demonstrate large-scale, unhindered retreat across reverse beds. 


\section{Substrate geology}

Through ice deformation alone, rates of ice flow velocity do not exceed a few tens of meters per year (24); therefore, faster ice flow of hundreds to thousands of meters per year requires basal sliding and/or subglacial sediment deformation (16). Basal motion is a fundamental function of basal friction and effective pressure $(16,25)$. Substrate geology plays a crucial role in determining frictional resistance to flow (25), the ease of erosion, and whether subglacial sediments support pressurized meltwater at the bed $(7,10,26)$. Recent experimental and modeling studies demonstrate that high velocities may, in fact, occur on both rigid- and soft-sediment substrates when basal water pressure is high and/or the yield strength of till is exceeded, such that the high flow speeds become insensitive to basal resistance $(10,11,27,28)$. Nonetheless, both modern and paleoobservations suggest that ice streaming is most commonly supported by saturated subglacial sediments $(7,9,14,26)$. We predict crystalline bedrock at the ice-bed interface is preferentially associated with nonstreaming ice flow in the absence of a deformable bed and enhanced frictional resistance, while unlithified sediments and lithified sedimentary bedrock are preferentially associated with streaming ice flow. Because of greater potential for basal traction and reduced ice flux, we predict that crystalline beds also have a stabilizing effect on the grounding line.

\section{Characterizing glacial "modes" and bed settings}

We test this series of predictions using geographically diverse, glacial landform-based datasets from the world's glaciated continental margins (Figs. 1 and 2 and table S1). On the basis of landform assemblages, we identify unique combinations of basal thermal regime and ice flow and retreat styles (Fig. 2) and refer to these combinations as a "glacial mode" (table S1 and Materials and Methods). Our approach assumes that glacial modes manifest as discernible landforms and therefore favors the most recent and most geomorphologically active modes of ice flow and retreat.

Basal thermal regime is classified as warm-based, mixed warmand cold-based, or indiscernible (Fig. 2A). We identify warm-based ice by the presence of bedforms and landforms indicating ice flow and bed deformation such as, but not limited to, glacial lineations, grounding zone wedges, and basal meltwater landforms. Mixed thermal regimes are recognized by the interspersion of bedforms/ landforms associated with warm- and cold-based ice, such as glaciotectonic landforms $(29,30)$.

Ice flow regime is categorized as streaming, nonstreaming, and indiscernible (Fig. 2B), predominantly on the basis of the form and distribution of subglacial bedforms. Mega-scale glacial lineations are widely considered diagnostic of paleo-ice streams $(31,32)$, and, while understanding of their formation remains incomplete, their greater length and elongation appears related to low basal shear stress and/ or sustained high ice flow velocities (33-35). Conversely, drumlins and ribbed moraines commonly occur in regions of slower flow or ice stream onsets, while short lineations interspersed with longer varieties are interpreted as "immature" individuals $(34,36,37)$. We therefore identify former streaming by the presence of bundles of mega-scale glacial lineations $(31,33)$ or streamlined bedrock features such as megagrooves and ridges (38). Nonstreaming or, qualitatively, "moderate" flow is denoted by ribbed moraines, drumlins, and glacial lineations limited in size, extent, and/or distribution (Fig. 2B), while the presence of grounding line landforms alone also indicates that till had been mobilized by flowing ice.
Retreat style is classed as consistent, inconsistent, featuring a readvance where a grounding line landform overrides a prior retreat assemblage, and indiscernible where grounding line landforms are lacking (Fig. 2C). The consistency of retreat events is the most objective property to infer from landform data rather than a relative rate (e.g., slow, rapid). Consistency is arguably more instructive, as it informs predictability of behavior in response to forcing. We consider grounding line retreat to be consistent if both the size and spacing of individual grounding line landforms are similar (i.e., within the same order of magnitude) to the preceding and following landforms and inconsistent if size and spacing are otherwise variable.

Our dataset comprises 99 formerly glaciated sites from both contemporary and Quaternary ice sheets, distributed across troughs $(n=51)$, fjords $(n=13)$, basins $(n=8)$, and banks $(n=27$; Materials and Methods, Fig. 1, and fig. S1). In each case, the predominant trend in catchment-scale bed slope is characterized as normal (deepening in direction of ice flow and shallowing in direction of retreat) or reverse (shallowing in direction of ice flow and deepening in direction of retreat) (fig. S1). Where variations in slope preclude a straightforward characterization, we consider these bed slopes variable. The geology of the substrate is broadly characterized as unlithified sediment, lithified sedimentary bedrock, or crystalline (igneous/ metamorphic) bedrock (Materials and Methods). We note cases of transition across combinations of these broad substrate classes and, for the purposes of first-order analysis, group these cases representing a "hard"-"soft"substrate transition, where hard and soft refer to the ease with which the substrate can be eroded and mobilized. Where high-frequency variability in substrate precludes any of these classifications, we consider these beds as otherwise variable. We recognize, however, that any single classification may include occasional patchiness and that such local variability may be important for individual landform generation (38).

\section{RESULTS}

Of the 99 geographic sites that we examined (Fig. 1), we recognize a total of 198 distinct glacial modes consisting of unique combinations of thermal regime and ice flow and retreat styles, representing an average of 2.00 unique glacial modes per site. The mean number of glacial modes in troughs (1.96), fjords (2.00), and banks (1.78) is rather consistent, while the maximum number (4) of glacial modes per site is the same for all settings except for a single trough with five glacial modes. These results indicate that regional topography does not dictate the diversity of thermal regime and flow and retreat behavior (Fig. 3A); all topographic types have the potential to host equally diverse glacial behavior.

\section{Topographic controls on glacial modes}

The overwhelming majority of glacial modes (94\%, $n=186)$ across all topographic types show evidence of warm-based ice (Fig. 3B). The few examples of glacial modes with mixed warm- and coldbased thermal regimes $(n=5)$ occur in troughs and on banks, and glacial modes with indiscernible thermal regime $(n=7)$ occur in all settings except basins.

Most of the glacial modes occurring in troughs are characterized by streaming ice flow (72\%; Fig. 3C). Streaming cases are overrepresented in troughs compared to both the proportion of trough assemblages (53\%) and of all streaming examples (56\%) in our dataset. Fifty-eight percent of identified glacial modes in fjords feature 
A

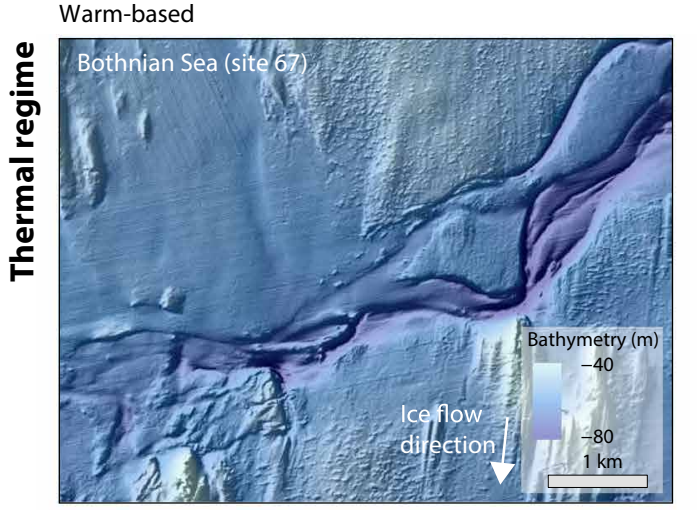

B

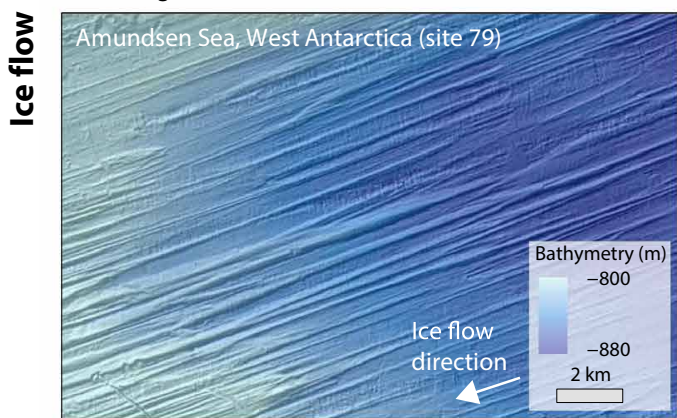

C

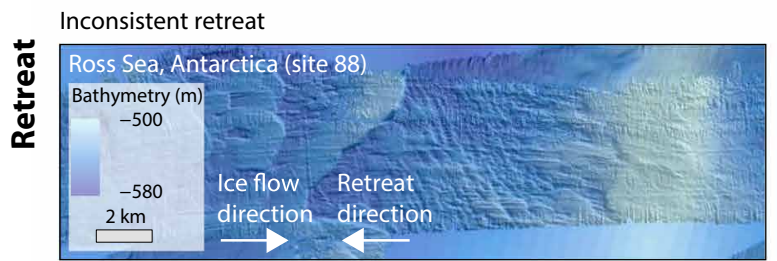

Readvance over prior retreat assemblage

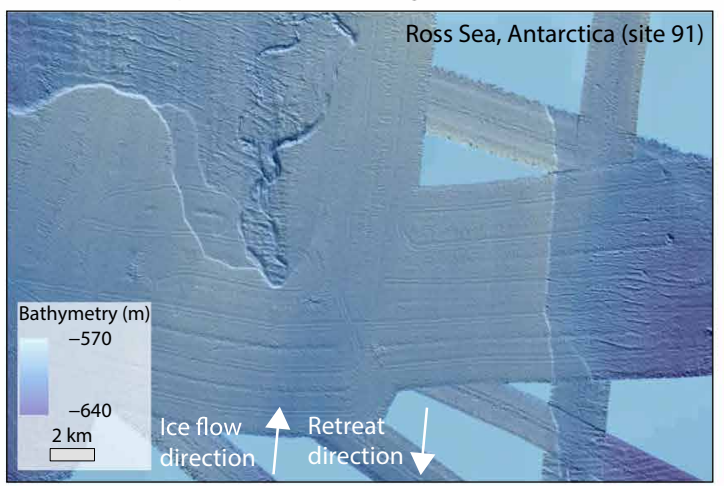

Mixed warm- and cold-based

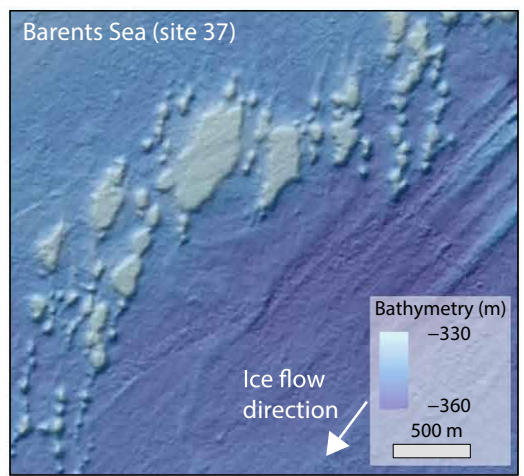

Nonstreaming, moderate

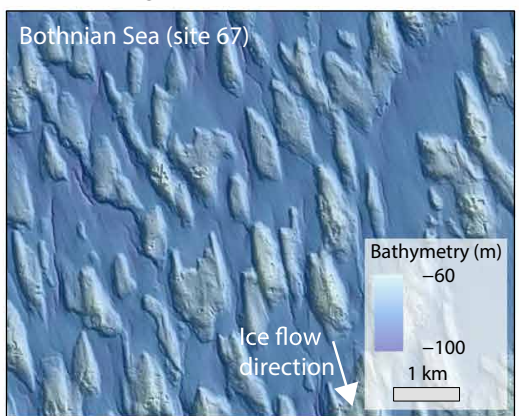

Consistent retreat

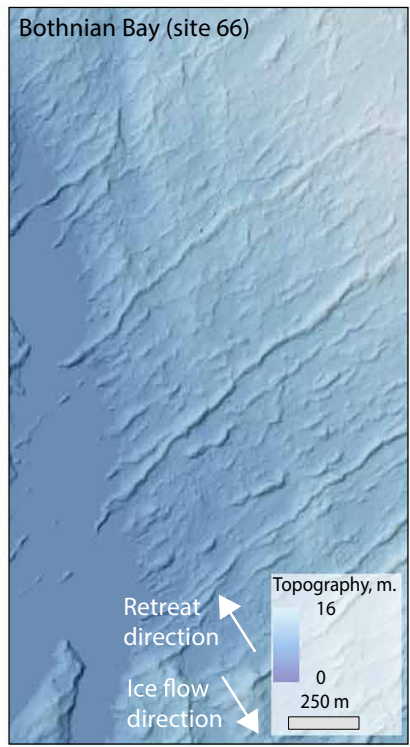

Fig. 2. Landform-based examples of glacial modes from glaciated continental shelves. (A) Thermal regime is classified as warm based, mixed warm and cold based, and indiscernible. For example, warm-based conditions are represented by sediment-based subglacial channels and mixed thermal regimes are indicated by rafted sediment blocks. (B) Ice flow regime is classified as streaming, nonstreaming, or indiscernible. For example, streaming is indicated by the presence of mega-scale glacial lineations, while nonstreaming, moderate flow is denoted by drumlins. (C) Retreat style is classified as inconsistent, consistent, readvance, or indiscernible. For example, inconsistent retreat is represented by variable size and spacing of grounding line landforms, consistent retreat is marked by regular size and spacing of grounding line landforms, and readvance is marked by a grounding zone wedge that overrides a prior retreat assemblage. The example of inconsistent retreat also shows an example of glacial lineations limited in size and extent used to inform our nonstreaming ice flow mode.

streaming flow. These findings support our earlier prediction that topographic funneling should favor faster (i.e., streaming) flow. Of all glacial modes observed on banks, just under half (46\%) are interpreted as nonstreaming flow, and these moderate flow cases are overrepresented on banks compared to both the proportion of bank assemblages (24\%) and of moderate flow (28\%) in our dataset. Unexpectedly, however, a quarter of bank flow modes $(25 \%)$ are classified as streaming. 

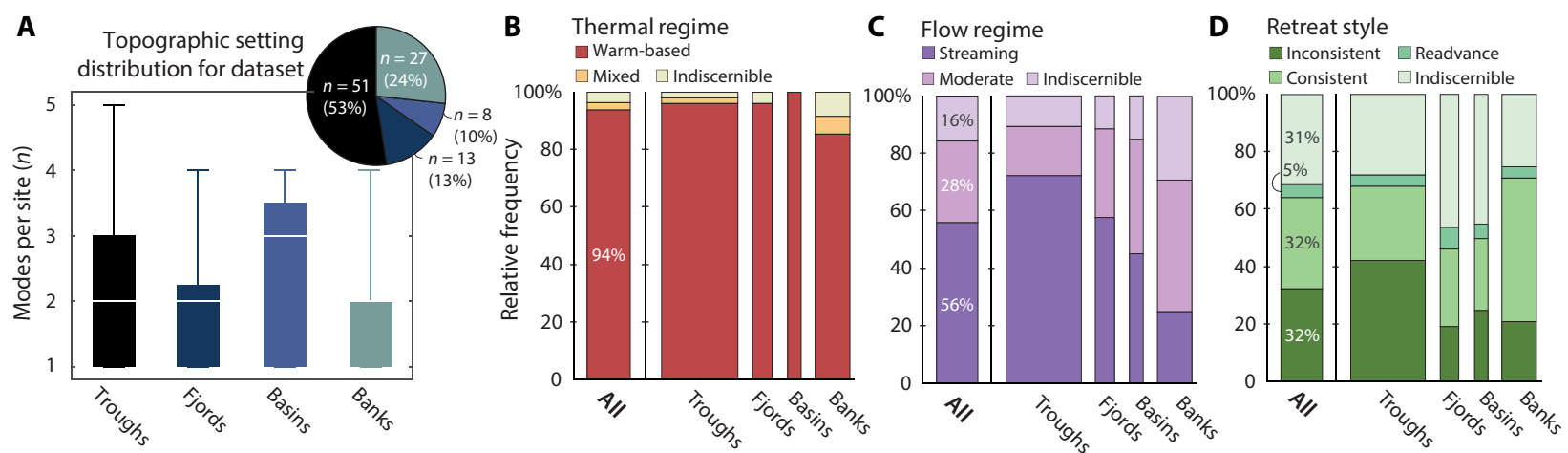

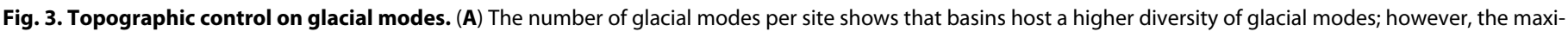

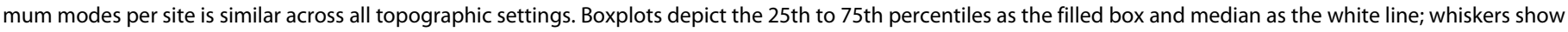

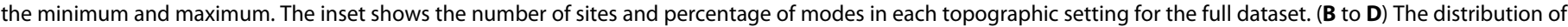
thermal regimes, ice flow regimes, and retreat styles within each topographic setting. The width of the bars scales with the percentage shown in the inset of (A).

All styles of grounding line retreat, except for readvance, are found in substantial proportions (19 to 50\%) in all topographic landscape types (Fig. 3D), on which basis we find that a topographic setting does not uniquely host a particular style of retreat. Yet, inconsistent retreat occurs more commonly in troughs ( $42 \%$ of trough cases) than it does in fjords, basins, and on banks (19 to $25 \%$ of cases in these settings). Half of all banks, meanwhile, host consistent grounding line retreat, while this setting and this retreat style account for just 24 and $32 \%$ of their respective classification groups. Nonetheless, of all consistent retreat cases, a greater proportion in fact occurs in troughs (43\%) than on banks (38\%), revealing ambiguous topographic control on the occurrence of consistent grounding line retreat behavior. Only $5 \%$ of the glacial modes in our dataset show evidence of grounding line readvance, indicating either genuine rarity of such behavior during deglaciation or the difficulty in recognizing it in the paleogeomorphic record where an earlier retreat assemblage may have been obscured or erased.

\section{Bed slope controls on glacial modes}

All bed slopes host all flow regimes (Fig. 4, A and B). Different flow styles occur more equally on normal slopes than they do on reverse slopes, where moderate flow is rare (only $10 \%$ of reverse slopes and $7 \%$ of all moderate flow cases) and where stream flow is instead overrepresented (73\% of reverse slopes; Fig. 4, A and B). This suggests that reverse bed slopes-despite lower driving stresses-are associated with faster flow. Streaming itself is not, however, contingent upon there being a reverse bed.

Bed slope is a poor predictor of retreat style: All slope settings show all types of retreat in similar proportions (Fig. 4C). Reverse bed slopes have received considerable attention in the context of grounding line retreat, suggested to be inherently unstable (5), although retreat may be modulated by local topography, bed conditions, and ice shelf buttressing $(22,23)$. Our dataset indicates that $75 \%$ of glacial modes reported from reverse-sloping beds are associated with either inconsistent retreat or retreat unmarked by grounding line landforms, consistent with how we predict MISI-like retreat to manifest in the landform record. These retreat styles themselves are, however, not limited to reverse slope settings and are rather evenly distributed across different topography (Fig. 4C). Across all reverse-sloping sites studied here, no examples of glacial readvance were identified. Notably, the remaining $25 \%$ of reverse bed cases
( $n=10$ ) house consistent grounding line retreat in which the magnitude of each backstep and sedimentation at the grounding line remains similar across a retreat sequence.

Normal-sloping beds host a diversity of retreat styles, but consistent retreat is most common ( $42 \%$ of normal beds), with a slight overrepresentation of this retreat style compared to the whole dataset (32\%). Both inconsistent retreat and indiscernible retreat are also relatively common on normal slopes, accounting for 28 and $25 \%$ of these settings, respectively (Fig. $4 \mathrm{C}$ ). We therefore find that, while certain retreat styles are favored on certain bed slopes, the direction of slope is not a universal determinant of grounding line retreat style.

\section{Substrate controls on glacial modes}

The frequency with which different flow regimes occur on different geological substrates very closely mirrors the occurrence of those substrate types across our whole dataset (Fig. 4, D and E). Stream flow, in particular and rather unexpectedly, shows little preferential occurrence or absence on any substrate type (notwithstanding the six cases where substrate geology is highly variable). Moderate flow shows some underrepresentation among unlithified substrates and overrepresentation on those that transition between hard and soft (Fig. 4E), perhaps supporting the hypothesis that acceleration can be facilitated by the presence of or a transition to soft sediments, but this is not reflected in the stream data themselves. Crystalline beds favor cases of indiscernible flow over moderate flow but, unexpectedly, exhibit streaming flow in proportions equal to both the occurrence of crystalline beds and the occurrence of streams in our complete dataset.

Consistent, inconsistent, and indiscernible retreat unmarked by landforms each account for just under one-third of our dataset. As in the case of flow style, the frequency with which different substrates support different modes of retreat closely mirrors the occurrence of those retreat styles across the entire dataset (Fig. 4F). Only crystalline beds ( $7 \%$ of our dataset) deviate from the overall distribution, favoring retreat in the absence of grounding line landforms (57\% of crystalline beds) over inconsistent retreat (just 14\%); consistent retreat is neither under- nor overrepresented on hard beds compared to other substrates. We find that the style of margin retreat-whether consistent, inconsistent, readvancing, or unmarked-is largely insensitive to the type of substrate. 

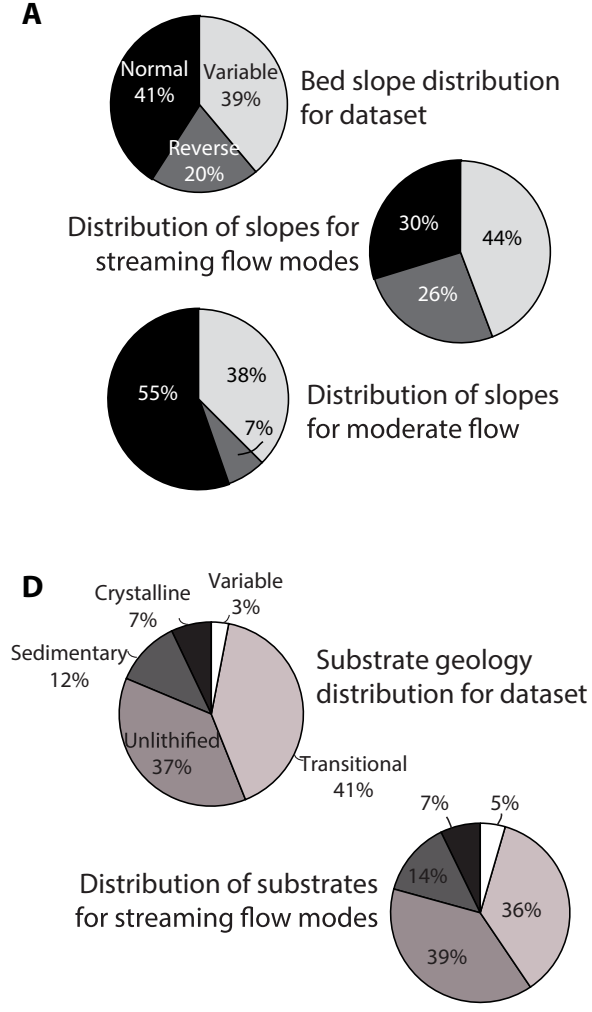

B
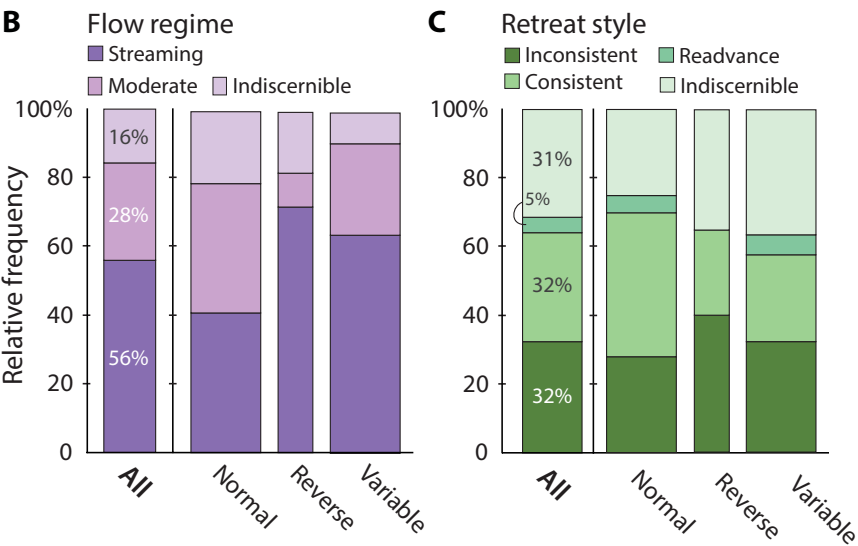

$\mathbf{E}$
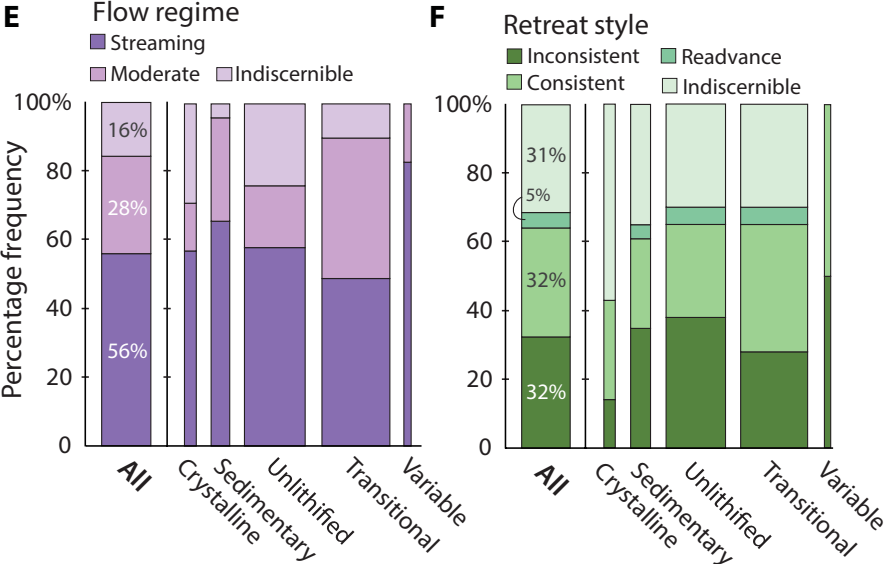

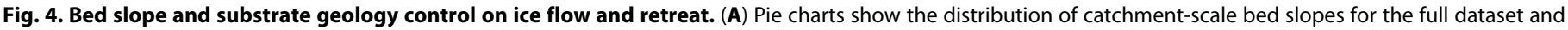

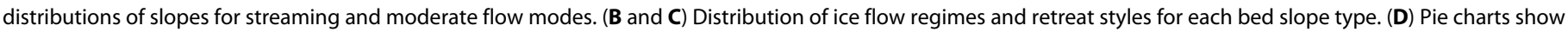

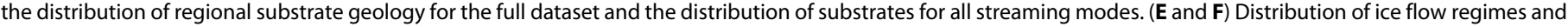
retreat styles for each substrate type. The width of bars [(B), (C), (E), and (F)] scales with the percentage of modes within each classification type.

\section{DISCUSSION}

\section{Insensitivity of thermal regime}

The overwhelming predominance of warm-based glacial modes in our dataset indicates an insensitivity of thermal regime to topographic or substrate setting (Fig. 3B). While our landform-based approach is inherently biased toward conditions that favor basal sediment mobility and construction of a variety of landforms, we do identify landforms associated with basal freeze-on (e.g., hill-hole pairs and rafted sediment blocks; Fig. 2A) and thus, at least, a mixed basal thermal regime (30). The fact that these are rarely observed suggests that, despite the acknowledged bias in our approach, warm-based ice dominates deglacial systems on continental margins, notwithstanding topography and bed substrate. This insensitivity of thermal regime is despite the variability in geothermal heat flux that we can expect across our geographically diverse database.

\section{Controls on ice flow}

Our analysis broadly confirms the predicted role of catchment-scale topography, finding that ice streams are overrepresented in troughs and fjords, while nonstreaming, moderate flow dominates bank settings. However, these relationships are not exclusive: Streaming flow is not limited to troughs and fjords but rather occurs in all topographic settings, and likewise, troughs and fjords are not always associated with streaming flow.
Contrary to our prediction, $25 \%$ of bank flow modes are characterized by streaming ice flow (Fig. 3C). Closer examination of these cases reveals that they encompass a variety of geographic settings: the East Antarctic margin, Ross Sea, Norwegian margin, and Barents Sea (table S1). We find that banks that permit streaming are lower in amplitude (both in absolute terms and scaled according to their width) than banks on which moderate flow occurs, while these streams drain substantially larger catchments and are positioned a much greater distance from the ice divide than cases of nonstreaming, moderate flow on banks (Fig. 5). The larger catchment size implies that streams occurring on banks may not be initiated on the bank itself but rather reflect ice streams with high supply exceeding the capacity of adjacent or upstream troughs/fjords. There appears to be an amplitude:width threshold of $\sim 2.5 \mathrm{~m} / \mathrm{km}$, below which banks host streaming flow, indicating that the sensitivity of ice flow to bed routing can be overcome. A scale dependency similarly distinguishes smaller ice rumples with faster ice flow velocities in contemporary ice shelves compared to slower and more variable flow of larger ice rises (39); impedance to flow depends on the size of the obstacle.

Our data reject the prediction that normal bed slopes more commonly support streaming ice flow than do reverse slopes (Fig. 4, A and B). We find instead that regional-scale reverse beds primarily host streaming flow and that these very rarely experience moderate flow, 

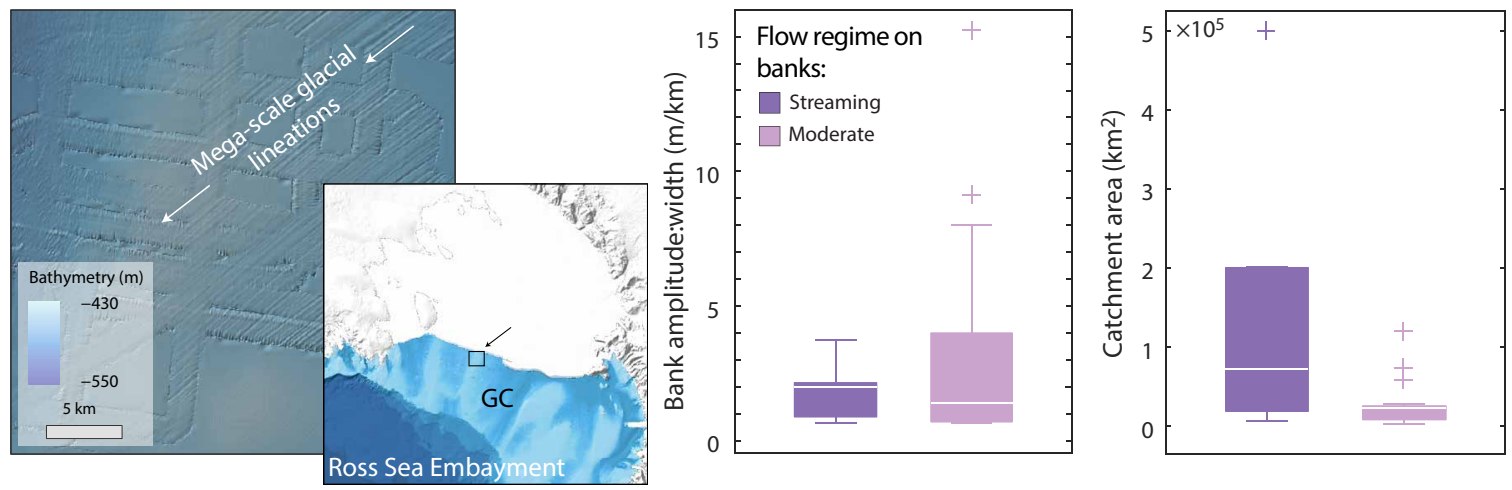

Fig. 5. Banks that support ice streams have lower amplitude and drain larger catchments than banks with nonstreaming, moderate flow. For example, Hayes Bank (site 87) is a low-amplitude bank (60-m relief over 30-km width), drains a portion of the $>3 \times 10^{6} \mathrm{~km}^{2}$ Ross Sea catchment, and is overrun by mega-scale glacial lineations indicating streaming flow exceeding the capacity of the Glomar Challenger Basin (GC) to the west. Bathymetry in main panel is from GeoMapApp (Global Multi-Resolution Topography v. 3.7); inset bathymetry and ice cover are from the International Bathymetric Chart of the Southern Ocean. Boxplots depict the 25th to 75th percentiles as the filled box and median as the white line; whiskers show the minimum and maximum excluding outliers (crosses), which are defined as values exceeding $1.5 \times$ the interquartile range from either the minimum or maximum value.

which is instead overrepresented on normal bed slopes. This indicates that the driving stress relationship with bed aspect is not a fundamental determinant of ice flow speed. We suggest that several potential effects may operate here. Reverse bed slopes occur overwhelmingly in troughs (table S2), which, in turn, favor ice streaming (Fig. 3C), suggesting that bed aspect is likely subordinate to wider topographic setting as a control on ice flow style. Second, the distribution of streaming on different bed slopes deviates only minimally from the occurrence of different bed slope classes in our full dataset, whereas moderate flow clearly favors normal slopes. This would suggest that the faster the ice flow, the less sensitive it may be to underlying bed slope; once operational, other factors sustain ice streaming and any sensitivity to bed aspect is overcome. Furthermore, MISI predicts $(5,6)$ and observations confirm [e.g., $(40,41)$ ] that grounding line retreat on a reverse slope can trigger dynamic thinning and flow acceleration: In this way, evolving flow style is not wholly independent of retreat behavior.

Streaming landform assemblages show no preferential occurrence or absence on any substrate type (Fig. 4, D and E). Contrary to our expectations and previous findings [cf. $(7,9,14)]$, therefore, we find that streaming flow is not dictated by substrate geology alone. That streaming flow can be maintained on all substrates is, in fact, consistent with some observations of ice streams on hard beds $(38,42)$ and with developments in sliding law theory demonstrating that, at high velocities, sliding becomes insensitive to basal drag even on hard beds [i.e., Coulomb-like sliding behavior $(11,27)]$. Above a threshold velocity, the bed no longer increases its resistance to sliding and stream flow can attain speeds independent of the substrate-determined basal drag. Our results not only support these theoretical developments but additionally demonstrate that the likelihood of ice streaming is independent of the type of substrate geology on which it rests. A particular substrate geology is not more or less likely to support ice streaming velocities than another.

In our dataset, streaming on crystalline beds tends to occur in negative relief settings where the amplitude of the topography preferentially funnels flow and drives acceleration. However, on unconsolidated beds, we must look beyond topographic setting to explain why streaming ice flow is not preferential as expected. Streaming can be expected when basal friction and/or effective pressure is low, conditions that are facilitated when the bed is saturated. Basal drag is reduced on impermeable (hard) beds where basal water pressure is sufficient to fill cavities (27). On unconsolidated (soft) beds, high basal water pressures weaken till resistance (shear strength) and enhance both slip and shear deformation of the till $(10,26,28)$. Therefore, while the geology of the substrate determines the specific mechanism for driving fast flow and the requisite water volumes and time for saturation, a high meltwater supply facilitates, qualitatively, the same flow style. We hypothesize that ice stream occurrence is more contingent on the supply of meltwater than the particular substrate with which it interacts.

\section{Controls on ice retreat}

Regional topographic setting (troughs, fjords, basins, or banks) alone does not define the style of grounding line retreat, with all observed styles (except readvance) common in all settings (Fig. 3D). We suggest that both the unpredictability of retreat style across all settings and, in fact, the two trends that do, albeit weakly, meet our expectations point to variability in the relative importance of lateral and basal drag [cf. $(17,43)]$. Banks are laterally unconfined but shallow (often systematically shallowing), giving dominance to basal drag and a predictable, consistent pattern of retreat. On the other hand, the tendency for an inconsistent pattern of retreat in troughs arises from the opposing and often spatiotemporally variable effects of lateral confinement and depth-modulated basal pressure. Common occurrence of other retreat styles in both settings further suggests that relative balance between lateral and basal effects is not straightforward. Notable is that indiscernible retreat, unmarked by grounding line landforms - perhaps lacking pinning at all-is encountered in at least $25 \%$ of all cases in both bank and trough settings (Fig. 3D). While regional-scale topographic setting is a poor predictor of grounding line retreat style, local-scale topography (i.e., pinning points and topographic constrictions) appears important for reliable characterization of retreat style [cf. $(18,44)]$.

We can, in part, confirm our prediction of bed slope-modulated retreat style: $75 \%$ of modes on reverse slopes exhibit an inconsistent grounding line retreat pattern or do not record grounding line landforms. Retreat proceeds in an irregular (unstable) manner or without sufficient pause or sufficient sediment to generate landforms at the 
grounding line. This is in accordance with the theory of MISI on bed slopes that deepen inland: Reverse slopes undergo a threshold response to forcing and/or are governed by sporadic pinning points to produce an inconsistent pattern of grounding line change. While we are cautious about interpreting rates of retreat from the spatial pattern of grounding line landforms (or lack thereof), it is possible that some of our documented cases represent collapse of the marginal zone of the catchment.

The common occurrence of inconsistent and unmarked retreat on reverse slopes is not, however, an exclusive occurrence: Both styles of retreat occur widely in other slope settings (Fig. 4C). If unmarked retreat can be interpreted as a consequence of decoupling from the bed, then a reverse bed slope is not a precondition for triggering such a collapse. Conversely, $25 \%$ of retreat cases on reverse slopes undergo regular, consistent (predictable) retreat, and these cases therefore exhibit an element of control or resilience in a system that theoretically should not be present because of slope alone $(5,6)$ but may be buffered by other factors $(22,23)$. There is no single factor in our dataset that satisfactorily explains the exhibited resilience, but we find that, in these cases, the mean ratio of relief amplitude to width (i.e., steepness and narrowness of the topography) is greater than cases of other retreat styles or in other slope settings, and catchment sizes are typically larger (Fig. 6). In other words, when supply of ice to the grounding line can be sustained, and where lateral pinning is effective and systematic, retreat may proceed steadily even on a deepening slope that should theoretically accelerate retreat [e.g., (18)]. However, if we consider a grounding line readvance to represent an even greater degree of system resilience, then it is notable that we, first, rarely detect this behavior in the landform record and, second, do not detect any instances of readvance on reverse bed slopes.

Unexpectedly, we find that the style of grounding line retreat is largely insensitive to the type of substrate (Fig. 4F). Model sensitivity testing $(44,45)$ has shown that soft (i.e., rheologically plastic) beds may, in the short term, slow retreat because thinning (melt) is quickly spread over a wider area, upstream of the grounding line. However, since a large area then thins toward flotation, this primes the soft-bedded system for delayed but rapid and widespread destabilization. Thinning on hard (i.e., rigid) beds, in contrast, is focused at the grounding line, and the retreat response time is therefore short but smaller in magnitude. Experiments further suggest (44) that the pattern of grounding line retreat, revealed by the positions where the grounding line pauses, is governed by the distribution of subcatchment-scale basal highs that act as pinning points and that this behavior is largely independent of the basal rheology. In our approach, we exclusively consider patterns of grounding line retreat. Our finding that the regional-scale pattern of retreat is insensitive to catchment substrate is therefore not necessarily incompatible with model findings that substrate rheology may control rates of grounding line change. We do, however, acknowledge that substrate rheology and local-scale topography may not be independent of each other and that, for example, a hard rheology more likely has more local roughness obstacles that would serve as pinning points.

Independent of either setting or substrate we find that, among ice streams, inconsistent ( $41 \%$ of stream cases) and unmarked (34\%) retreat are overrepresented, while consistent retreat is overrepresented among cases of moderate flow. These relationships suggest that the style of ice flow can predispose a system to a certain mode of retreat or vice versa. A concerning outcome from this study is that, irrespective of bed characteristics and geographically controlled conditions (e.g., climate), grounding line readvance over decadal to millennial time scales is not a behavior that the paleorecord supports as a savior for contemporary glacial systems.

\section{Predictability of marine ice sheet behavior}

As expected, on the basis of theoretical, numerical, and conceptual approaches, empirical observations demonstrate a systematic correspondence between topographic funneling and streaming ice flow, reverse bed slopes and inconsistent or unmarked retreat, and normal/ variable bed slopes and consistent retreat, indicating a high degree of predictability in flow and retreat style associated with these specific bed properties. However, important exceptions to these rules make a prediction of marine ice sheet evolution based on consideration of catchment-scale bed characteristics alone too simplistic.
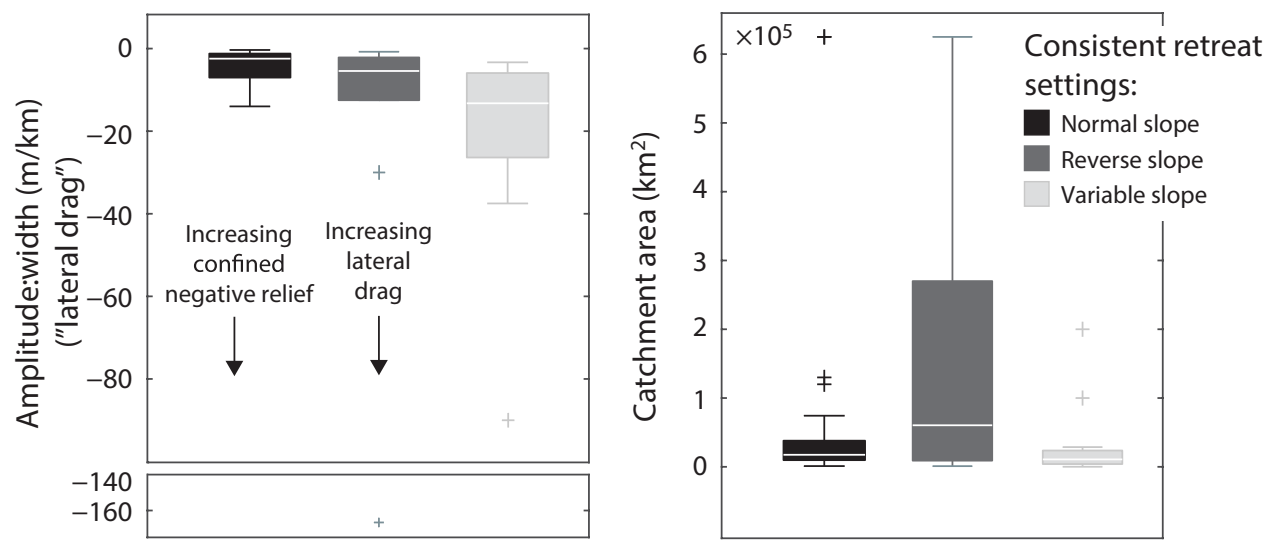

Fig. 6. Enhanced lateral drag and high supply to the grounding line may help facilitate controlled, consistent retreat on reverse bed slopes. Among all consistent retreat cases, those on reverse slopes occur in steeper/narrower negative-relief topographic settings (i.e., may experience greater lateral drag) than cases on normal slopes. Reverse slope cases of consistent retreat are supplied by larger catchments than normal or variable slopes. Note that variable slopes show yet more lateral drag and the reverse slope catchment sizes show a large range; neither factor provides a complete explanation. Boxplots depict the 25 th to 75 th percentiles as the filled box and median as the white line; whiskers show the minimum and maximum excluding outliers (crosses), which are defined as values exceeding $1.5 \times$ the interquartile range from either the minimum or maximum value. 
We find notable exceptions where primary catchment-scale controls on ice flow have been overcome: Banks can host ice streams, bed slope becomes less important the faster the flow, and the resistance of hard beds can be muted. Our dataset suggests that, once ice streams are initiated, they can be maintained in topographic and geological settings other than those that act as an initial driver. In other words, we hypothesize that fast flow can be "inherited" from settings or time periods that were more favorable for triggering flow acceleration and that, once operational, ice stream flow becomes less sensitive to the bed. This is in keeping with observations and recent advances in sliding law theory showing that, at high flow velocities, basal motion becomes decoupled from basal shear stress $(11,28)$. On this basis, there may be a commitment of some ice sheet sectors to fast flow and high discharges even as they retreat into different landscape settings, which has implications for the temporal setup of numerical ice sheet models (e.g., spin-up time or prior flow/retreat behavior as boundary conditions); flow history is important.

A particular example of inherited behavior that we find in the landform record is coupling between flow and retreat dynamics that occurs independent of bed conditions: Styles of flow can predispose a system to a style of retreat, and vice versa. This is consistent with contemporary observations of grounding line change, where grounding line retreat into deeper water has been accompanied by flow acceleration [e.g., $(40,41)]$. Conversely, faster flowing catchments are capable of more rapidly transmitting a forcing signal through the catchment (41), which may furthermore feedback into a grounding line response. Where streaming flow exists, our dataset suggests a high chance of inconsistent or unmarked retreat irrespective of regional topographic setting and substrate properties.

While the style of ice flow appears to, in some particular cases, overcome expected catchment-scale controls, our dataset indicates that retreat style can deviate from expected patterns because of sensitivity to local topography and the challenges of untangling the relative importance of lateral and basal drag at a subcatchment scale. Retreat behavior on banks is relatively predictable because of a lack of (topographically driven) lateral drag and therefore predominance of basal effects. In settings where both lateral and basal drag vary (e.g., troughs), predicting retreat behavior is more difficult; our records of past retreat behavior demonstrate great inconsistency. The effect of bed slope is similarly equivocal at catchment scale. Predicting the consistency or inconsistency of grounding line retreat requires adequate representation of local topography (lateral and basal pinning, and slope variability and magnitude, at subcatchment scale) in models $(18,44,45)$.

One unexpected finding is a weak association between ice flow and retreat styles with bed substrate, seemingly contrary to theoretical and modeling predictions $(45,46)$ and behaviors inferred from the observational record $(9,12,14)$. Coulomb-type sliding relationships describe comparable flow behavior on both hard $(11,27)$ and soft $(10,28)$ beds, with the bed providing (near) finite resistance to high flow velocities; the magnitude of drag and mechanisms of sliding differ according to the substrate, but the behavior is, qualitatively, the same. Our findings are in keeping with this body of work, while they also show that cases of streaming flow occur on different geological substrates with equal likelihood. We suggest that this reflects the importance of meltwater in regulating ice-bed coupling and the pervasiveness of Coulomb-style sliding. Supply of meltwater to the bed and resultant high basal water pressure facilitates fast ice flow in both hard $(8,27,47)$ and soft bed $(26)$ systems. Depending on the geology, a substrate will require different water volumes and time to reach saturation. That we do not see a correspondence between fast flow and substrate geology in our post-Last Glacial Maximum dataset suggests that none of these geographically and climatologically diverse systems have been persistently meltwater-limited.

Given the high potential for spatiotemporal variability of subglacial hydrology (relative to the underlying geology) and the first-order insensitivity of marine-based flow and retreat to substrate geology, we suggest that effective prediction of ice sheet behavior preferentially requires knowledge of meltwater supply. This is particularly true for marine-based catchments, where the uptake of overburden by the water column brings the system much closer to thresholds necessary for meltwater supply to overwhelm subglacial drainage pathways.

Examination of an extensive dataset of geomorphic archives of ice flow and retreat indicates that the evolution of marine-based ice sheets cannot be reliably predicted on the basis of catchment-scale basal topography and substrate conditions alone. We hypothesize that local topographic variation, inheritance of ice flow style, coupling between ice flow and retreat style, and meltwater supply are all important influences that complicate predictions of ice sheet behavior based on first-order theoretical considerations of the interaction of an ice sheet with its bed. Compared with catchment-scale bed properties, these factors have a high degree of spatial and temporal variability and complexity that must be better characterized to improve the predictability of ice flow and retreat behavior.

\section{MATERIALS AND METHODS}

We analyze high-resolution acoustic bathymetric datasets from the margins of Antarctica, Greenland, the northwest European margin (Britain and Ireland, the North Sea, and Norwegian Sea to the Barents Sea), Iceland, eastern Canada, Patagonia, and sub-Antarctic islands. From each marine ice sheet system, we catalog observed glacial landforms, systematically interpret their paleoglaciological context, and report data sources. To analyze the topographic and substrate settings of these glacial landform assemblages, we draw on regional to global bathymetric datasets including the International Bathymetric Chart of the Arctic Ocean (48), the International Bathymetric Chart of the Southern Ocean (49), and the General Bathymetric Chart of the Oceans (50); available regional geological maps, often from national surveys or reported literature [e.g., (51)]; and interpretations of continental shelf seismic stratigraphy and drill/sediment core information [e.g., $(13,52)]$. The vast majority of sites record ice behavior during deglaciation from (and in some cases at) the Last Glacial Maximum. However, we do not draw on absolute chronologies of ice flow and retreat in our analysis, since these are notoriously challenging to determine (53). This precludes an examination of timedependent changes in paleotopography resulting from glacial isostatic adjustment as well as relative and eustatic sea level change.

For all sites, we record the occurrence of subglacial bedforms (glacial lineations, drumlins, crag-and-tails, streamlined bedrock, glaciotectonic rafts, and ribbed moraine), glaciofluvial landforms (eskers and channels), and ice-marginal landforms (grounding zone wedges, moraines, ice-marginal deltas, and crevasse-squeeze ridges). We use the occurrence of landforms indicative of the former basal thermal regime (Fig. 2A), ice flow style (Fig. 2B), and retreat style (Fig. 2C) to define a glacial mode: a unique combination of these three facets of former ice sheet behavior in any given site. Any site may express multiple glacial modes or multiple examples of a single 
mode, reflecting spatiotemporal change or consistency in flow and retreat style. Our interpretations hinge on the assumption that specific modes of ice flow and retreat create a geomorphological imprint, which inherently biases us toward the most recent and most geomorphologically active modes of ice flow and retreat. All indiscernible cases do not host indicative landforms and could represent (i) truly cold-based ice, (ii) "lift-off" retreat, (iii) masking by postglacial sediments, or (iv) insufficient data coverage and/or resolution to distinguish between "no landforms exist" and "no landforms seen" scenarios.

We consider bed characteristics at a glacial catchment scale. Troughs are defined as elongate topographic lows bounded by higher relief on the lateral margins, extending tens to hundreds of kilometers in any orientation with respect to the continental shelf or surrounding land. Fjords are laterally constrained by subaerial land extending tens to hundreds of kilometers. Basins are topographic lows surrounded by higher relief with closed elevation contours and diameters tens to hundreds of kilometers, while banks are similarly sized topographic highs with closed contours surrounded by lower relief (fig. S1). Bed substrate geology is classified broadly as crystalline (igneous or metamorphic lithologies), sedimentary bedrock, unlithified sediments, or encompassing a transition from a hard to soft bed. Where data permit, we refer wherever possible to the substrate geology encountered by ice flow at the Last Glacial Maximum, removing the postglacial marine sediment cover.

\section{SUPPLEMENTARY MATERIALS}

Supplementary material for this article is available at http://advances.sciencemag.org/cgi/ content/full/7/3/eabb6291/DC1

\section{REFERENCES AND NOTES}

1. G. K. C. Clarke, U. Nitsan, W. S. B. Paterson, Strain heating and creep instability in glaciers and ice sheets. Rev. Geophys. Space Phys. 15, 235-247 (1977).

2. A. J. Payne, P. W. Dongelmans, Self-organization in the thermomechanical flow of ice sheets. J. Geophys. Res. Solid Earth 102, 12219-12233 (1997).

3. R. C. A. Hindmarsh, Consistent generation of ice-streams via thermo-viscous instabilities modulated by membrane stresses. Geophys. Res. Lett. 36, L06502 (2009).

4. M. C. M. Winsborrow, C. D. Clark, C. R. Stokes, What controls the location of ice streams? Earth Sci. Rev. 103, 45-59 (2010).

5. C. Schoof, Ice sheet grounding line dynamics: Steady states, stability, and hysteresis. J. Geophys. Res. Earth Surf. 112, F03S28 (2007).

6. J. Weertman, Stability of the junction of an ice sheet and an ice shelf. J. Glaciol. 13, 3-11 (1974).

7. R. B. Alley, D. D. Blankenship, C. R. Bentley, S. T. Rooney, Deformation of till beneath ice stream B, West Antarctica. Nature 322, 57-59 (1986).

8. B. Kamb, Glacier surge mechanism based on linked cavity configuration of the basal water conduit system. J. Geophys. Res. Solid Earth 92, 9083-9100 (1987).

9. S. Anandakrishnan, D. D. Blankenship, R. B. Alley, P. L. Stoffa, Influence of subglacial geology on the position of a West Antarctic ice stream from seismic observations. Nature 394, 62-65 (1998).

10. S. Tulaczyk, W. B. Kamb, H. F. Engelhardt, Basal mechanics of ice stream B, West Antarctica: 1. Till mechanics. J. Geophys. Res. Solid Earth 105, 463-481 (2000)

11. I. Joughin, B. E. Smith, C. G. Schoof, Regularized Coulomb friction laws for ice sheet sliding: Application to Pine Island Glacier, Antarctica. Geophys. Res. Lett. 46, 4764-4771 (2019).

12. D. Ottesen, C. R. Stokes, L. Rise, L. Olsen, Ice-sheet dynamics and ice streaming along the coastal parts of northern Norway. Quat. Sci. Rev. 27, 922-940 (2008).

13. A. R. W. Halberstadt, L. M. Simkins, S. L. Greenwood, J. B. Anderson, Past ice-sheet behaviour: Retreat scenarios and changing controls in the Ross Sea, Antarctica. Cryosphere 10, 1003-1020 (2016).

14. J. S. Wellner, A. L. Lowe, S. S. Shipp, J. B. Anderson, Distribution of glacial geomorphic features on the Antarctic continental shelf and correlation with substrate: implications for ice behavior. J. Glaciol. 47, 397-411 (2001).

15. J. A. Dowdeswell, M. Canals, M. Jakobsson, B. J. Todd, E. K. Dowdeswell, K. A. Hogan, Atlas of Submarine Glacial Landforms: Modern, Quaternary and Ancient (Geological Society of London, 2016).

16. K. M. Cuffey, W. S. B. Paterson, The Physics of Glaciers (Academic Press, 2010).
17. I. M. Whillans, C. J. van der Veen, The role of lateral drag in the dynamics of Ice Stream B, Antarctica. J. Glaciol. 43, 231-237 (1997).

18. S. S. R. Jamieson, A. Vieli, S. J. Livingstone, C. Ó. Cofaigh, C. Stokes, C.-D. Hillenbrand, J. A. Dowdeswell, Ice-stream stability on a reverse bed slope. Nat. Geosci. 5, 799-802 (2012).

19. J. J. Fürst, G. Durand, F. Gillet-Chaulet, L. Tavard, M. Rankl, M. Braun, O. Gagliardini, The safety band of Antarctic ice shelves. Nat. Clim. Chang. 6, 479-482 (2016).

20. S. S. Jacobs, A. Jenkins, C. E. Giulivi, P. Dutrieux, Stronger ocean circulation and increased melting under Pine Island Glacier ice shelf. Nat. Geosci. 4, 519-523 (2011).

21. H. Seroussi, Y. Nakayama, E. Larour, D. Menemenlis, M. Morlighem, E. Rignot, A. Khazendar, Continued retreat of Thwaites Glacier, West Antarctica, controlled by bed topography and ocean circulation. Geophys. Res. Lett. 44, 6191-6199 (2017).

22. G. H. Gudmundsson, J. Krug, G. Durand, L. Favier, O. Gagliardini, The stability of grounding lines on retrograde slopes. Cryosphere 6, 1497-1505 (2012).

23. A. A. Robel, C. Schoof, E. Tziperman, Persistence and variability of ice-stream grounding lines on retrograde bed slopes. Cryosphere 10, 1883-1896 (2016).

24. E. Rignot, J. Mouginot, B. Scheuchl, Ice flow of the Antarctic ice sheet. Science 333, 1427-1430 (2011).

25. J. Weertman, On the sliding of glaciers. J. Glaciol. 3, 33-38 (1957).

26. M. Bougamont, P. Christoffersen, A. L. Hubbard, A. A. Fitzpatrick, S. H. Doyle, S. P. Carter Sensitive response of the Greenland Ice Sheet to surface melt drainage over a soft bed. Nat. Commun. 5, 5052 (2014).

27. C. Schoof, The effect of cavitation on glacier sliding. Proc. R. Soc. A Math. Phys. Eng. Sci. 461, 609-627 (2005).

28. L. K. Zoet, N. R. Iverson, A slip law for glaciers on deformable beds. Science 368, 76-78 (2020).

29. J. Sættem, Glaciotectonic forms and structures on the Norwegian continental shelf: Observations, processes and implications. Norsk Geologisk Tidsskrift 70, 81-94 (1990).

30. K. Andreassen, M. Winsborrow, Signature of ice streaming in Bjørnøyrenna, Polar North Atlantic, through the Pleistocene and implications for ice-stream dynamics. Ann. Glaciol. 50, 17-26 (2009).

31. C. R. Stokes, C. D. Clark, Geomorphological criteria for identifying Pleistocene ice streams. Ann. Glaciol. 28, 67-74 (1999).

32. M. Spagnolo, C. D. Clark, J. C. Ely, C. R. Stokes, J. B. Anderson, K. Andreassen, A. G. C. Graham, E. C. King, Size, shape and spatial arrangement of mega-scale glacial lineations from a large and diverse dataset. Earth Surf. Process. Landf. 39, 1432-1448 (2014).

33. E. C. King, R. C. A. Hindmarsh, C. R. Stokes, Formation of mega-scale glacial lineations observed beneath a West Antarctic ice stream. Nat. Geosci. 2, 585-588 (2009).

34. S. S. R. Jamieson, C. R. Stokes, S. J. Livingstone, A. Vieli, C. Ó. Cofaigh, C.-D. Hillenbrand, M. Spagnolo, Subglacial processes on an Antarctic ice stream bed. 2: Can modelled ice dynamics explain the morphology of mega-scale glacial lineations? J. Glaciol. 62, 285-298 (2016).

35. N. Holschuh, K. Christianson, J. Paden, R. B. Alley, S. Anandakrishnan, Linking postglacial landscapes to glacier dynamics using swath radar at Thwaites Glacier, Antarctica. Geology 48, 268-272 (2020)

36. C. R. Stokes, M. Spagnolo, C. D. Clark, C. Ó. Cofaigh, O. B. Lian, R. B. Dunstone, Formation of mega-scale glacial lineations on the Dubawnt Lake Ice Stream bed: 1. Size, shape and spacing from a large remote sensing dataset. Quat. Sci. Rev. 77, 190-209 (2013).

37. S. J. Livingstone, C. R. Stokes, C. Ó. Cofaigh, C.-D. Hillenbrand, A. Vieli, S. S. R. Jamieson, M. Spagnolo, J. A. Dowdeswell, Subglacial processes on an Antarctic ice stream bed. 1: Sediment transport and bedform genesis inferred from marine geophysical data. J. Glaciol. 62, 270-284 (2016).

38. M. Krabbendam, N. Eyles, N. Putkinen, T. Bradwell, L. Arbelaez-Moreno, Streamlined hard beds formed by palaeo-ice streams: A review. Sediment. Geol. 338, 24-50 (2016).

39. K. Matsuoka, R. C. A. Hindmarsh, G. Moholdt, M. J. Bentley, H. D. Pritchard, J. Brown, H. Conway, R. Drews, G. Durand, D. Goldberg, T. Hattermann, J. Kingslake, J. T. M. Lenaerts, C. Martín, R. Mulvaney, K. W. Nicholls, F. Pattyn, N. Ross, T. A. Scambos, P. L. Whitehouse, Antarctic ice rises and rumples: Their properties and significance for ice-sheet dynamics and evolution. Earth Sci. Rev. 150, 724-745 (2015).

40. I. M. Howat, I. Joughin, M. Fahnestock, B. E. Smith, T. A. Scambos, Synchronous retreat and acceleration of southeast Greenland outlet glaciers 2000-06: Ice dynamics and coupling to climate. J. Glaciol. 54, 646-660 (2008).

41. J. Mouginot, E. Rignot, B. Scheuchl, Sustained increase in ice discharge from the Amundsen Sea Embayment, West Antarctica, from 1973 to 2013. Geophys. Res. Lett. 41, 1576-1584 (2014).

42. C. R. Stokes, C. D. Clark, Laurentide ice streaming on the Canadian Shield: A conflict with the soft-bedded ice stream paradigm? Geology 31, 347-350 (2003)

43. C. Bunce, J. R. Carr, P. W. Nienow, N. Ross, R. Killick, Ice front change of marine-terminating outlet glaciers in northwest and southeast Greenland during the 21 st century. J. Glaciol. 64, 523-535 (2018)

44. S. Koellner, B. R. Parizek, R. B. Alley, A. Muto, N. Holschuh, The impact of spatially-variable basal properties on outlet glacier flow. Earth Planet. Sci. Lett. 515, 200-208 (2019).

45. B. R. Parizek, K. Christianson, S. Anandakrishnan, R. B. Alley, R. T. Walker, R. A. Edwards, D. S. Wolfe, G. T. Bertini, S. K. Rinehart, R. A. Bindschadler, S. M. J. Nowicki, 
Dynamic (in)stability of Thwaites Glacier, West Antarctica. J. Geophys. Res. Earth Surf. 118, 638-655 (2013).

46. S. J. Marshall, G. K. C. Clarke, A. S. Dyke, D. A. Fisher, Geologic and topographic controls on fast flow in the Laurentide and Cordilleran Ice Sheets. J. Geophys. Res. Solid Earth 101, 17827-17839 (1996).

47. C. Schoof, Ice-sheet acceleration driven by melt supply variability. Nature 468, 803-806 (2010).

48. M. Jakobsson, L. Mayer, B. Coakley, J. A. Dowdeswell, S. Forbes, B. Fridman, H. Hodnesdal, R. Noormets, R. Pedersen, M. Rebesco, H. W. Schenke, Y. Zarayskaya, D. Accettella, A. Armstrong, R. M. Anderson, P. Bienhoff, A. Camerlenghi, I. Church, M. Edwards, J. V. Gardner, J. K. Hall, B. Hell, O. Hestvik, Y. Kristoffersen, C. Marcussen, R. Mohammad, D. Mosher, S. V. Nghiem, M. T. Pedrosa, P. G. Travaglini, P. Weatherall, The International Bathymetric Chart of the Arctic Ocean (IBCAO) version 3.0. Geophys. Res. Lett. 39, L12609 (2012).

49. J. E. Arndt, H. W. Schenke, M. Jakobsson, F. O. Nitsche, G. Buys, B. Goleby, M. Rebesco, F. Bohoyo, J. Hong, J. Black, R. Greku, G. Udintsev, F. Barrios, W. Reynoso-Peralta, M. Taisei, R. Wigley, The International Bathymetric Chart of the Southern Ocean (IBCSO) version 1.0-A new bathymetric compilation covering circum-Antarctic waters. Geophys. Res. Lett. 40, 3111-3117 (2013).

50. P. Weatherall, K. M. Marks, M. Jakobsson, T. Schmitt, S. Tani, J. E. Arndt, M. Rovere, D. Chayes, V. Ferrini, R. Wigley, A new digital bathymetric model of the world's oceans. Earth Space Sci. 2, 331-345 (2015).

51. E. M. O. Sigmond, Geological Map of Land and Sea Areas of Northern Europe, Scale 1:4 Million (Geological Survey of Norway, 2002).

52. A. M. W. Newton, P. C. Knutz, M. Huuse, P. Gannon, S. H. Brocklehurst, O. R. Clausen, Y. Gong, Ice stream reorganization and glacial retreat on the northwest Greenland shelf. Geophys. Res. Lett. 44, 7826-7835 (2017).

53. C. Subt, K. A. Fangman, J. S. Wellner, B. E. Rosenheim, Sediment chronology in Antarctic deglacial sediments: Reconciling organic carbon ${ }^{14} \mathrm{C}$ ages to carbonate ${ }^{14} \mathrm{C}$ ages using Ramped PyrOx. Holocene 26, 265-273 (2016).

54. C. L. Batchelor, M. Margold, M. Krapp, D. K. Murton, A. S. Dalton, P. L. Gibbard, C. R. Stokes, J. B. Murton, A. Manica, The configuration of Northern Hemisphere ice sheets through the Quaternary. Nat. Commun. 10, 3713 (2019).

55. RAISED Consortium, M. J. Bentley, C. Ó. Cofaigh, J. B. Anderson, H. Conway, B. Davies, A. G. C. Graham, C.-D. Hillenbrand, D. A. Hodgson, S. S. R. Jamieson, R. D. Larter, A. Mackintosh, J. A. Smith, E. Verleyen, R. P. Ackert, P. J. Bart, S. Berg, D. Brunstein, M. Canals, E. A. Colhoun, X. Crosta, W. A. Dickens, E. Domack, J. A. Dowdeswell, R. Dunbar, W. Ehrmann, J. Evans, V. Favier, D. Fink, C. J. Fogwill, N. F. Glasser, K. Gohl, N. R. Golledge, I. Goodwin, D. B. Gore, S. L. Greenwood, B. L. Hall, K. Hall, D. W. Hedding, A. S. Hein, E. P. Hocking, M. Jakobsson, J. S. Johnson, V. Jomelli, R. S. Jones, J. P. Klages, Y. Kristoffersen, G. Kuhn, A. Leventer, K. Licht, K. Lilly, J. Lindow, S. J. Livingstone, G. Masse, M. S. McGlone, R. M. McKay, M. Melles, H. Miura, R. Mulvaney, W. Nel, F. O. Nitsche, P. E. O'Brien, A. L. Post, S. J. Roberts, K. M. Saunders, P. M. Selkirk, A. R. Simms, C. Spiegel, T. D. Stolldorf, D. E. Sugden, T. van Ommen, D. Verfaillie, W. Vyverman, B. Wagner, D. A. White, A. E. Witus, D. Zwartz, A community-based geological reconstruction of Antarctic Ice Sheet deglaciation since the Last Glacial Maximum. Quat. Sci. Rev. 100, 1-9 (2014).

56. J. Shaw, D. J. W. Piper, G. B. J. Fader, E. L. King, B. J. Todd, T. Bell, M. J. Batterson, D. G. E. Liverman, A conceptual model of the deglaciation of Atlantic Canada. Quat. Sci. Rev. 25, 2059-2081 (2006)

57. B. J. Todd, P. C. Valentine, O. Longva, J. Shaw, Glacial landforms on German Bank, Scotian Shelf: Evidence for Late Wisconsinan ice-sheet dynamics and implications for the formation of De Geer moraines. Boreas 36, 148-169 (2007).

58. E. Brouard, P. Lajeunesse, Maximum extent and decay of the Laurentide Ice Sheet in Western Baffin Bay during the last glacial episode. Sci. Rep. 7, 10711 (2017).

59. M. Jakobsson, K. A. Hogan, L. A. Mayer, A. Mix, A. Jennings, J. Stoner, B. Eriksson, K. Jerram, R. Mohammad, C. Pearce, B. Reilly, C. Stranne, The Holocene retreat dynamics and stability of Petermann Glacier in northwest Greenland. Nat. Commun. 9, 2104 (2018).

60. P. C. Knutz, J. R. Hopper, U. Gregersen, T. Nielsen, P. Japsen, A contourite drift system on the Baffin Bay-West Greenland margin linking Pliocene Arctic warming to poleward ocean circulation. Geology 43, 907-910 (2015).

61. J. A. Dowdeswell, K. A. Hogan, C. Ó. Cofaigh, E. M. G. Fugelli, J. Evans, R. Noormets, Late Quaternary ice flow in a West Greenland fjord and cross-shelf trough system: Submarine landforms from Rink Isbrae to Uummannaq shelf and slope. Quat. Sci. Rev. 92, 292-309 (2014).

62. J. A. Dowdeswell, K. A. Hogan, C. Ó. Cofaigh, Submarine glacial-landform distribution across the West Greenland margin: A fjord-shelf-slope transect through the Uummannaq system (70-71 N). Geol. Soc. Lond. Mem. 46, 453-460 (2016)

63. M. Spagnolo, C. D. Clark, A geomorphological overview of glacial landforms on the Icelandic continental shelf. J. Maps 5, 37-52 (2009).

64. H. Patton, A. Hubbard, T. Bradwell, A. Schomacker, The configuration, sensitivity and rapid retreat of the Late Weichselian Icelandic ice sheet. Earth Sci. Rev. 166, 223-245 (2017).

65. D. Ottesen, J. A. Dowdeswell, J. Y. Landvik, J. Mienert, Dynamics of the Late Weichselian ice sheet on Svalbard inferred from high-resolution sea-floor morphology. Boreas 36, 286-306 (2007).
66. K. Streuff, M. Forwick, W. Szczuciński, K. Andreassen, C. Ó. Cofaigh, Submarine landform assemblages and sedimentary processes related to glacier surging in Kongsfjorden, Svalbard. Arktos 1, 14 (2015)

67. D. J. Burton, J. A. Dowdeswell, K. A. Hogan, R. Noormets, Marginal fluctuations of a Svalbard surge-type tidewater glacier, Blomstrandbreen, since the Little Ice Age: A record of three surges. Arct. Antarct. Alp. Res. 48, 411-426 (2016).

68. J. A. Dowdeswell, D. Ottesen, M. Forwick, Grounding-zone wedges on the western Svalbard shelf. Geol. Soc. Lond. Mem. 46, 233-234 (2016).

69. K. A. Hogan, J. A. Dowdeswell, R. Noormets, J. Evans, C. Ó. Cofaigh, Evidence for fullglacial flow and retreat of the Late Weichselian Ice Sheet from the waters around Kong Karls Land, eastern Svalbard. Quat. Sci. Rev. 29, 3563-3582 (2010).

70. C. J. Batchelor, J. A. Dowdeswell, K. A. Hogan, Late Quaternary ice flow and sediment delivery through Hinlopen Trough, Northern Svalbard margin: Submarine landforms and depositional fan. Mar. Geol. 284, 13-27 (2011).

71. A. E. Flink, R. Noormets, O. Fransner, K. A. Hogan, M. O'Regan, M. Jakobsson, Past ice flow in Wahlenbergfjorden and its implications for late Quaternary ice sheet dynamics in northeastern Svalbard. Quat. Sci. Rev. 163, 162-179 (2017).

72. O. Fransner, R. Noormets, A. E. Flink, K. A. Hogan, M. O'Regan, M. Jakobsson, Glacial landforms and their implications for glacier dynamics in Rijpfjorden and Duvefjorden, northern Nordaustlandet, Svalbard. J. Quat. Sci. 32, 437-455 (2017).

73. K. A. Hogan, J. A. Dowdeswell, R. Noormets, J. Evans, C. Ó. Cofaigh, M. Jakobsson, Submarine landforms and ice-sheet flow in the Kvitøya Trough, northwestern Barents Sea. Quat. Sci. Rev. 29, 3545-3562 (2010).

74. L. R. Bjarnadóttir, M. C. M. Winsborrow, K. Andreassen, Deglaciation of the central Barents Sea. Quat. Sci. Rev. 92, 208-226 (2014).

75. L. R. Bjarnadóttir, M. C. M. Winsborrow, K. Andreassen, Large subglacial meltwater features in the central Barents Sea. Geology 45, 159-162 (2017).

76. M. Esteves, L. R. Bjarnadóttir, M. C. M. Winsborrow, C. S. Shackleton, K. Andreassen, Retreat patterns and dynamics of the Sentralbankrenna glacial system, central Barents Sea. Quat. Sci. Rev. 169, 131-147 (2017).

77. A. M. W. Newton, M. Huuse, Glacial geomorphology of the central Barents Sea: Implications for the dynamic deglaciation of the Barents Sea Ice Sheet. Mar. Geol. 387, 114-131 (2017).

78. T. Nielsen, T. L. Rasmussen, Reconstruction of ice sheet retreat after the Last Glacial Maximum in Storfjorden, southern Svalbard. Mar. Geol. 402, 228-243 (2018).

79. T. L. Rasmussen, E. Thomsen, M. A. Ślubowska, S. Jessen, A. Solheim, N. Koç, Paleoceanographic evolution of the SW Svalbard margin $\left(76^{\circ} \mathrm{N}\right)$ since $20,000{ }^{14} \mathrm{C} \mathrm{yr} \mathrm{BP}$. Quatern. Res. 67, 100-114 (2007).

80. M. Łącka, M. Zajączkowski, M. Forwick, W. Szczuciński, Late Weichselian and Holocene palaeoceanography of Storfjordrenna, southern Svalbard. Clim. Past 11, 587-603 (2015)

81. R. G. Lucchi, A. Camerlenghi, M. Rebesco, E. Colmenero-Hidalgo, F. J. Sierro, L. Sagnotti, R. Urgeles, R. Melis, C. Morigi, M.-A. Bárcena, G. Giorgetti, G. Villa, D. Persico, J.-A. Flores, A. S. Rigual-Hernández, M. T. Pedrosa, P. Macri, A. Caburlotto, Postglacial sedimentary processes on the Storfjorden and Kveithola trough mouth fans: Significance of extreme glacimarine sedimentation. Global Planet. Change 111, 309-326 (2013).

82. L. R. Bjarnadóttir, D. C. Rüther, M. C. M. Winsborrow, K. Andreassen, Grounding-line dynamics during the last deglaciation of Kveithola, W Barents Sea, as revealed by seabed geomorphology and shallow seismic stratigraphy. Boreas 42, 84-107 (2013).

83. D. C. Rüther, R. Mattingsdal, K. Andreassen, M. Forwick, K. Husum, Seismic architecture and sedimentology of a major grounding zone system deposited by the Bjørnøyrenna Ice Stream during Late Weichselian deglaciation. Quat. Sci. Rev. 30, 2776-2792 (2011).

84. K. Andreassen, M. C. M. Winsborrow, L. R. Bjarnadóttir, D. C. Rüther, Ice stream retreat dynamics inferred from an assemblage of landforms in the northern Barents Sea. Quat. Sci. Rev. 92, 246-257 (2014).

85. K. Andreassen, L. C. Nilssen, L. Rafaelsen, L. Kuilman, Three-dimensional seismic data from the Barents Sea margin reveal evidence of past ice streams and their dynamics. Geology 32, 729-732 (2004).

86. D. C. Rüther, K. Andreassen, M. Spagnolo, Aligned glaciotectonic rafts on the central Barents Sea seafloor revealing extensive glacitectonic erosion during the last deglaciation. Geophys. Res. Lett. 40, 6351-6355 (2013).

87. E. D. Piasecka, M. C. M. Winsborrow, K. Andreassen, C. R. Stokes, Reconstructing the retreat dynamics of the Bjørnøyrenna Ice Stream based on new 3D seismic data from the central Barents Sea. Quat. Sci. Rev. 151, 212-227 (2016).

88. M. C. M. Winsborrow, K. Andreassen, G. D. Corner, J. S. Laberg, Deglaciation of a marinebased ice sheet: Late Weichselian palaeo-ice dynamics and retreat in the southern Barents Sea reconstructed from onshore and offshore glacial geomorphology. Quat. Sci. Rev. 29, 424-442 (2010).

89. D. Ottesen, J. A. Dowdeswell, L. Rise, Submarine landforms and the reconstruction of fast-flowing ice streams within a large Quaternary ice sheet: The 2500-km-long Norwegian-Svalbard margin $\left(57^{\circ}-80^{\circ} \mathrm{N}\right)$. Geol. Soc. Am. Bull. 117, 1033-1050 (2005).

90. K. Andreassen, J. S. Laberg, T. O. Vorren, Seafloor geomorphology of the SW Barents Sea and its glaci-dynamic implications. Geomorphology 97, 157-177 (2008). 
91. M. C. M. Winsborrow, C. R. Stokes, K. Andreassen, Ice-stream flow switching during deglaciation of the southwestern Barents Sea. Geol. Soc. Am. Bull. 124, 275-290 (2012).

92. M. Winsborrow, K. Andreassen, A. Hubbard, A. Plaza-Faverola, E. Gudlaugsson, H. Patton, Regulation of ice stream flow through subglacial formation of gas hydrates. Nat. Geosci. 9, 370-374 (2016).

93. T. O. Vorren, L. Plassen, Deglaciation and palaeoclimate of the Andfjord- Vågsfjord area, North Norway. Boreas 31, 97-125 (2002).

94. J. S. Laberg, R. S. Eilertsen, G. R. Salomonsen, T. O. Vorren, Submarine push moraine formation during the early Fennoscandian Ice Sheet deglaciation. Quatern. Res. 67, 453-462 (2007).

95. S. L. Greenwood, C. C. Clason, J. Nyberg, M. Jakobsson, P. Holmlund, The Bothnian Sea ice stream: Early Holocene retreat dynamics of the south-central Fennoscandian Ice Sheet. Boreas 46, 346-362 (2017).

96. T. Bradwell, D. Small, D. Fabel, R. K. Smedley, C. D. Clark, M. H. Saher, S. L. Callard, R. C. Chiverrell, D. Dove, S. G. Moreton, D. H. Roberts, G. A. T. Duller, C. Ó. Cofaigh, Ice-stream demise dynamically conditioned by trough shape and bed strength. Sci. Adv. 5, eaau1380 (2019).

97. T. Bradwell, M. S. Stoker, Submarine sediment and landform record of a palaeo-ice stream within the British-Irish Ice Sheet. Boreas 44, 255-276 (2015).

98. M. Stoker, T. Bradwell, C. Wilson, C. Harper, D. Smith, C. Brett, Pristine fjord landsystem revealed on the sea bed in the Summer Isles region, NW Scotland. Scottish J. Geol. 42, 89-99 (2006).

99. M. S. Stoker, T. Bradwell, J. A. Howe, I. P. Wilkinson, K. McIntyre, Lateglacial ice-cap dynamics in NW Scotland: Evidence from the fjords of the Summer Isles region. Quat. Sci. Rev. 28, 3161-3184 (2009).

100. T. Bradwell, M. S. Stoker, N. R. Golledge, C. K. Wilson, J. W. Merritt, D. Long, J. D. Everest, O. B. Hestvik, A. G. Stevenson, A. L. Hubbard, A. G. Finlayson, H. E. Mathers, The northern sector of the last British Ice Sheet: Maximum extent and demise. Earth Sci. Rev. 88, 207-226 (2008).

101. H. P. Sejrup, C. D. Clark, B. O. Hjelstuen, Rapid ice sheet retreat triggered by ice stream debuttressing: Evidence from the North Sea. Geology 44, 355-358 (2016).

102. M. A. Stewart, L. Lonergan, G. Hampson, 3D seismic analysis of buried tunnel valleys in the central North Sea: Morphology, cross-cutting generations and glacial history. Quat. Sci. Rev. 72, 1-17 (2013).

103. A. G. C. Graham, L. Lonergan, M. S. Stoker, Evidence for Late Pleistocene ice stream activity in the Witch Ground Basin, central North Sea, from 3D seismic reflection data. Quat. Sci. Rev. 26, 627-643 (2007).

104. D. H. Roberts, E. Grimoldi, L. Callard, D. J. A. Evans, C. D. Clark, H. A. Stewart, D. Dove, M. Saher, C. Ó. Cofaigh, R. C. Chiverrell, M. D. Bateman, S. G. Moreton, T. Bradwell, D. Fabel, A. Medialdea, The mixed-bed glacial landform imprint of the North Sea Lobe in the western North Sea. Earth Surf. Process. Landf. 44, 1233-1258 (2019).

105. K. J. J. Van Landeghem, A. J. Wheeler, N. C. Mitchell, Seafloor evidence for palaeo-ice streaming and calving of the grounded Irish Sea Ice Stream: Implications for the interpretation of its final deglaciation phase. Boreas 38, 119-131 (2009).

106. J. A. Dowdeswell, M. Vásquez, Submarine landforms in the fjords of southern Chile: Implications for glacimarine processes and sedimentation in a mild glacier-influenced environment. Quat. Sci. Rev. 64, 1-19 (2013).

107. A. G. C. Graham, P. T. Fretwell, R. D. Larter, D. A. Hodgson, C. K. Wilson, A. J. Tate, P. Morris, A new bathymetric compilation highlighting extensive paleo-ice sheet drainage on the continental shelf, South Georgia, sub-Antarctica. Geochem. Geophys. Geosyst. 9, Q07011 (2008).

108. E. Domack, D. Amblàs, R. Gilbert, S. Brachfeld, A. Camerlenghi, M. Rebesco, M. Canals, R. Urgeles, Subglacial morphology and glacial evolution of the Palmer deep outlet system, Antarctic Peninsula. Geomorphology 75, 125-142 (2006).

109. C. Lavoie, E. W. Domack, E. C. Pettit, T. A. Scambos, R. D. Larter, H.-W. Schenke, K. C. Yoo, J. Gutt, J. Wellner, M. Canals, J. B. Anderson, D. Amblas, Configuration of the Northern Antarctic Peninsula Ice Sheet at LGM based on a new synthesis of seabed imagery. Cryosphere 9, 613-629 (2015).

110. Y.P. Muñoz, J. S. Wellner, Seafloor geomorphology of western Antarctic Peninsula bays: A signature of ice flow behaviour. Cryosphere 12, 205-225 (2018).

111. J. B. Anderson, L. O. Fretwell, Geomorphology of the onset area of a paleo-ice stream, Marguerite Bay, Antarctic Peninsula. Earth Surf. Process. Landf. 33, 503-512 (2008).

112. C. Ó. Cofaigh, C. J. Pudsey, J. A. Dowdeswell, P. Morris, Evolution of subglacial bedforms along a paleo-ice stream, Antarctic Peninsula continental shelf. Geophys. Res. Lett. 29, 41-1-41-4 (2002).

113. C. Ó. Cofaigh, B. J. Davies, S. J. Livingstone, J. A. Smith, J. S. Johnson, E. P. Hocking D. A. Hodgson, J. B. Anderson, M. J. Bentley, M. Canals, E. Domack, J. A. Dowdeswell, J. Evans, N. F. Glasser, C.-D. Hillenbrand, R. D. Larter, S. J. Roberts, A. R. Simms, Reconstruction of ice-sheet changes in the Antarctic Peninsula since the Last Glacial Maximum. Quat. Sci. Rev. 100, 87-110 (2014).

114. R. D. Larter, J. B. Anderson, A. G. C. Graham, K. Gohl, C.-D. Hillenbrand, M. Jakobsson, J. S. Johnson, G. Kuhn, F. O. Nitsche, J. A. Smith, A. E. Witus, M. J. Bentley, J. A. Dowdeswell, W. Ehrmann, J. P. Klages, J. Lindow, C. Ó. Cofaigh, C. Spiegel, Reconstruction of changes in the Amundsen Sea and Bellingshausen Sea sector of the West Antarctic ice sheet since the last glacial maximum. Quat. Sci. Rev. 100, 55-86 (2014).

115. M. Jakobsson, J. B. Anderson, F. O. Nitsche, R. Gyllencreutz, A. E. Kirshner, N. Kirchner, M. O'Regan, R. Mohammad, B. Eriksson, Ice sheet retreat dynamics inferred from glacial morphology of the central Pine Island Bay Trough, West Antarctica. Quat. Sci. Rev. 38, $1-10$ (2012).

116. A. G. C. Graham, M. Jakobsson, F. O. Nitsche, R. D. Larter, J. B. Anderson, C.-D. Hillenbrand, K. Gohl, J. P. Klages, J. A. Smith, A. Jenkins, Submarine glacial-landform distribution across the West Antarctic margin, from grounding line to slope: The Pine Island-Thwaites ice-stream system. Geol. Soc. Lond. Mem. 46, 493-500 (2016).

117. A. G. C. Graham, F. O. Nitsche, R. D. Larter, K. Gohl, Submarine landform assemblage produced beneath the Dotson-Getz palaeo-ice stream, West Antarctica. Geol. Soc. Lond. Mem. 46, 345-348 (2016).

118. P. J. Bart, J. B. Anderson, F. Nitsche, Post-LGM grounding-line positions of the Bindschadler paleo-ice stream in the Ross Sea Embayment, Antarctica. J. Geophys. Res. Earth Surf. 122, 1827-1844 (2017).

119. P. J. Bart, B. J. Krogmeier, M. P. Bart, S. Tulaczyk, The paradox of a long grounding during West Antarctic Ice Sheet retreat in Ross Sea. Sci. Rep. 7, 1262 (2017).

120. P. J. Bart, M. DeCesare, B. E. Rosenheim, W. Majewski, A. McGlannan, A centuries-long delay between a paleo-ice shelf collapse and grounding-line retreat in the Whales Deep Basin, eastern Ross Sea, Antarctica. Sci. Rep. 8, 12392 (2018).

121. P. J. Bart, B. Owolana, On the duration of West Antarctic Ice Sheet grounding events in Ross Sea during the Quaternary. Quat. Sci. Rev. 47, 101-115 (2012).

122. S. L. Greenwood, R. Gyllencreutz, M. Jakobsson, J. B. Anderson, Ice-flow switching and East/West Antarctic Ice Sheet roles in glaciation of the western Ross Sea. Geol. Soc. Am. Bull. 124, 1736-1749 (2012).

123. L. M. Simkins, J. B. Anderson, S. L. Greenwood, H. M. Gonnerman, L. O. Prothro, A. R. W. Halberstadt, L. A. Stearns, D. Pollard, R. DeConto, Anatomy of a meltwater drainage system beneath the ancestral East Antarctic ice sheet. Nat. Geosci. 10, 691-697 (2017).

124. S. L. Greenwood, L. M. Simkins, A. R. W. Halberstadt, L. O. Protho, J. B. Anderson, Holocene reconfiguration and readvance of the East Antarctic Ice Sheet. Nat. Commun. 9, 3176 (2018).

125. J. I. Lee, R. M. McKay, N. R. Golledge, H. I. Yoon, K.-C. Yoo, H. J. Kim, J. K. Hong, Widespread persistence of expanded East Antarctic glaciers in the southwest Ross Sea during the last deglaciation. Geology 45, 403-406 (2017).

126. R. S. Jones, A. N. Mackintosh, K. P. Norton, N. R. Golledge, C. J. Fogwill, P. W. Kubik, M. Christl, S. L. Greenwood, Rapid Holocene thinning of an East Antarctic outlet glacier driven by marine ice sheet instability. Nat. Commun. 6, 8910 (2015).

127. K. McMullen, E. Domack, A. Leventer, C. Olson, R. Dunbar, S. Brachfeld, Glacial morphology and sediment formation in the Mertz Trough, East Antarctica. Palaeogeogr. Palaeoclimatol. Palaeoecol. 231, 169-180 (2006).

128. R. Fernandez, S. Gulick, E. Domack, A. Montelli, A. Leventer, A. Shevenell, B. Frederick; NBP1402 Science Party, Past ice stream and ice sheet changes on the continental shelf off the Sabrina Coast, East Antarctica. Geomorphology 317, 10-22 (2018).

129. J. M. Campo, J. S. Wellner, E. Domack, C. Lavoie, K.-C. Yoo, Glacial geomorphology of the northwestern Weddell Sea, eastern Antarctic Peninsula continental shelf: Shifting ice flow patterns during deglaciation. Geomorphology 280, 89-107 (2017).

Acknowledgments: We acknowledge UiT-CAGE, Kartverket, NGU, and MAREANO data sources as well as others who have made their data publicly available. Funding: We were funded by INQUA Coastal and Marine Processes grant 1602P and, in addition, by the Knut and Alice Wallenberg Foundation (to S.L.G., fellowship 2016.0144), the Research Council of Norway through its Centres of Excellence funding scheme (to M.C.M.W., grant 223259), and internal funding through the University of Virginia (to L.M.S.), and the Geological Survey of Norway (Norges Geologiske Undersøkelse) (to L.R.B.). Author contributions: L.R.B., S.L.G., L.M.S., and M.C.M.W. contributed equally to the work. All authors reviewed the manuscript. Competing interests: The authors declare that they have no competing interests. Data and materials availability: The datasets generated during the current study are available from the corresponding author on reasonable request. The original geophysical datasets are either publicly available, previously published, or perhaps available upon inquiry to the authors of the original study or principal investigator of the cruise on which the data were collected. See table $\mathrm{S} 1$ for details on data sources.

Submitted 7 March 2020

Accepted 20 November 2020

Published 13 January 2021

10.1126/sciadv.abb6291

Citation: S. L. Greenwood, L. M. Simkins, M. C. M. Winsborrow, L. R. Bjarnadóttir, Exceptions to bed-controlled ice sheet flow and retreat from glaciated continental margins worldwide. Sci. Adv. 7, eabb6291 (2021). 